\title{
Eclectic Model in the Malaysian Education System
}

\author{
Nooraini Othman (Corresponding Author) \\ UTM Perdana School, Universiti Teknologi Malaysia, International Campus, Jalan Semarak \\ 54100 Kuala Lumpur, Malaysia \\ Tel: 60-326-154-891Ｅ-mail: p-noraini@utm.my \\ Khairul Azmi Mohamad \\ Yayasan Ilmuwan \\ D-0-3A, Setiawangsa Business Suites, Taman Setiawangsa, 54200 Kuala Lumpur, Malaysia \\ Tel: 60-342-562-659Ｅ-mail: khairul3008@yahoo.com
}

Received: March 31, 2011 Accepted: April 15, $2011 \quad$ Published: November 1, 2011

doi:10.5539/ies.v4n4p111 URL: http://dx.doi.org/10.5539/ies.v4n4p111

\begin{abstract}
The present work aims at analysing the adoption of eclectic model in the Malaysian education system. The analysis is specifically looked from the angle of Islam and the Muslims. Malaysia has a long history of education system developments, from pre to post independence of the country. From what was initailly traditional, modernity later came to shape the system and practice. The British left many marks and continued to be inherited even after independence. Later, the education philosophy was changed and different approached to education were implemented. Progressing further, symbiotic approach where the normal or conventional academic content were coupled with the Islamic perspective on similar subject matter became part of the system. Eclectic model progresses further and appeared in the form of established higher education system and practice.
\end{abstract}

Keywords: Malaysian education system, Eclectic model, Symbiotic approach, Islamic perspective

\section{Introduction}

Malaysian education system has undergone a unique metamorphosis. It has its long history as a series of educational development process. From a system which was essentially traditional, it has now embrace modernity in its content and approach. From what was initially a Malay and Islamic based education, colonialism took place, one after the other, and thus introduced their own education systems such as Japanese education and English education. Post independence brought about different sets of development. Effort was put in place to bring back the prominence of Malay and Islam in the system while in the same time retaining some colonial legacy. Over a period of years of struggle, curriculum and approach continued to change and develop in order to come up with 'what is the best.'

A more recent development took place in the context of Islamisation. It is a process whereby unIslamic contents were weed out and replaced with what is Islamic. The next is by elaborating and giving the clearest picture of the Islamic perspectives of a particular subject. The process also involved challenging some established concepts and principles which are secular in nature.

The challenge is further a field as Islamisation has to be proven to be able to stand by itself in an established institution with a recognised curriculum. Such curriculum has to be professional enough in order to meet the demands of the market place and yet Islamic. The climax of this process is the establishment of the International Islamic University in Malaysia which enjoys a world class reputation while maintaining its Islamic identity and content. More institutions of this nature, government or private, have been established. It is proven that this approach which is integrated in nature is acceptable by the Muslims and non-Muslims alike, accreditation bodies world wide, professional organisations and world class employers. Certainly, efforts must be further put in order to ensure that the quality of this institution is further enhanced, not only that it is capable of attracting the best students and minds to come, but also capable of producing the best students and the best minds who will contribute towards the betterment of the ummah (Muslim community).

In the same direction, other education institutions may emulate the relevant model depending on the availability of expertise, leaderships and psychological readiness. A constructive symbiosis is only possible through a process 
involving a good amount of graduality, steadiness and consistency.

The present work aims at analysing some relevant developments in the Malaysian education system in relation to the Muslims. It will look at some foundational issues that contributed to the educational reform in Malaysia. Integrated approach is seen as one of the important parts of this reform.

\section{Historical Background of Educational Reform in Malaysia}

\subsection{The Islamic Education System}

Education, especially in the form of non-formal, is believed to develop along with the spread of Islam in this country during the fourteenth century. The Muslim traders from Arab and India were identified to be the agents who spread Islam and started the non-formal education through the building of the 'Pondok' schools in Perlis, Kedah, Melaka, Terengganu, Kelantan and Brunei (Sufean, 1996). Islamic education normally taught by the imam or religious teachers at the mosques during the night time. A more systematic religious education started at the sekolah pondok, the hut type religious schools and run by the ulama (Islamic religious scholars). These schools were located near the river side due to the mode of transportation prevalent at that particular time usually small boats or yachts. The curriculum was subject-centred; the method of study was traditional, primarily memorization and school discipline was strict. The focus of study was the revealed sciences, which covered the Qur'an; Sunnah (the prophetic tradition); theology; jurisprudence; history of Islam including the Prophet Muhammad's biography; fundamentals of arithmetic and logic (Rosnani, 2004). These educational institutions had a common goal of producing virtuous Muslims who would obey the religious commandments and be useful to society.

\subsection{Education during the British Colonial}

The current education system inherited from the British education system. The practice and educational policy made by the British for more than a decade ago has been conquering the mind of the society which affects the current structure of the National Education System. The British laissez-faire policy in education led to the existence of five types of schooling namely, the Malay vernacular, English vernacular, Chinese vernacular, Tamil vernacular and Religious Madrasah schools. The existence of these schools has some negative effects on the development of national education system which aims for national integration.

The existence of this vernacularism in the education system during the British Colonisation was influenced by the factors of political, economics, socio-cultural and religion. The British initially through Christian missionaries established English schools with English as the medium of instruction. With the establishment of these schools, dualism in education began in Malaysia. This dual system affected the Malays in the sense that most of the English schools were built in urban centers and proved inaccessible to the Malays who majority lived in the rural areas. Another factor which made these schools unpopular, even among Malay aristocrats, was the fear that students would be converted to Christianity. Furthermore, they had their own Islamic religious education (Sufean, 1996).

In order to ensure some level of literacy, the British later introduced Malay vernacular schools. It was only limited to creating better farmers and fishermen but not far stretchingly educated for the British worried that the population might rebel against them. Later the British succeeded in drawing a larger proportion of the Malay population into the English schools by making it a policy that only Malays literate in English would be employed in the administrative service and British-owned commercial houses. They also succeeded in changing the Malays perception of education from a socializing process with religion at the core, to an economic tool as a means for gaining material prosperity.

\section{Educational Reform after Independence}

It had been seen that the colonial master made every attempt to change the mind set of the indigenous of Malaya so that they subscribed to the philosophy, thoughts and the lifestyle of the British. As a result, the education system then had undergone some form of reformation following the mould of the colonial master. After independence the nationalist of the nation including the Malay Muslim educationist started to embark on the big national agenda to reshape the education system based on a new mould i.e. philosophically correct, conceptually modern, locally developed content and relevant to the actual need of this newly independent country.

Rosnani (2004) described educational reform after the independence as below:

After independence in 1957, the new government began a systematic drive towards achieving national unity through education. The British had left behind educational institutions which did not support the newly independent country's need for racial integration. Several new educational policies were therefore formulated to change the situation. The search for a national system of education to serve as the foundation for integrating the various ethnic groups, as well as the agent for socio-economic development, became one of the major concerns of Malaysian leaders. 
During this same period, Malay vernacular and English schools began to gain popularity among the Malays for economic and religious reasons. The teaching of Islamic religious knowledge in both the national schools (the former English schools) was recommended by the Razak Report submitted in 1956. In 1960 the government accepted the Rahman Talib Report and Islamic religious study was made compulsory for all Muslim students in all government schools. These efforts by the government hastened the decline of the Islamic schools, by lessening the need for private religious education.

Rosnani (2004) further analysed that although the religious schools experienced a decline in the late 1950's, interest returned in the 1970's with the resurgence of Islam in Malaysia. Islamic consciousness was strongly felt by the Muslim masses, and Islamic organizations sprang to life. Muslims expressed their dissatisfaction with the national system of education, which they regarded as secular. They called for educational reform in line with Islamic principles. In response to calls from various sectors, the government implemented a few educational reforms beginning in 1977, when the Ministry of Education introduced the national secondary religious schools (SMKA) for selected students based on high achievement in the Primary School Evaluation Examination (UPSR). The national secondary religious schools differ from the national secondary schools in that the former offer Arabic Language and higher Islamic religious study for all its students beginning in the first year of the secondary Religious school study.

In 1979 the Report of the Cabinet Committee on the Review of the Implementation of Education Policies recommended that all Muslim students be required to sit for Islamic religious knowledge in national examinations. In 1983, based on the same report, the Ministry of Education implemented the New Primary School Curriculum (KBSR). The curriculum emphasized the basic skills of writing, reading and arithmetic and the Malay Language. The periods devoted to Islamic religion was increased, and moral education was introduced for non-Muslim students. In 1987, a National Education Philosophy was formulated which expressed the aim of creating Malaysian citizens who are intellectually, spiritually, emotionally and physically balanced and harmonious, based on a firm belief in and devotion to God.

In 1989, following the formulation of the National Education Philosophy, the Ministry of Education launched the Integrated Curriculum for Secondary Schools (KBSM). The implementation of the integrated curriculum coincided with the entrance into secondary schools of the first generation of students who had completed the New Primary School Curriculum. The new curriculum emphasizes the growth of a balanced personality, the integration of universal values in all subjects taught, the greater use of Malay language across the curriculum, and an extension of general education for all students from nine to eleven years of age. In this curriculum, the number of periods devoted to Islamic religious instruction was increased and for non-Muslim students, the subject of moral education was introduced.

\section{Foundational Issues in Educational Reform}

There are several foundational issues came into picture relevant to the discussion which contributed to the educational reform in the Malaysian education system. The issues are secularism, dualism, holistic personality, Islamisation and integration.

\subsection{Secularism}

S. M. Naquib (1993) explained in his book, "Islam and Secularism":

The term secular comes from the Latin saeculum, conveys a meaning with a marked dual connotation of time and location; the time referring to the 'now' or 'present'sense of it, and the location to the 'world' or 'worldly' sense of it. Thus saeculum means 'this age' or 'the present time' refers to events in this world, and it also means 'contemporary events'. The concept secular refers to the condition of the world at this particular time. Secularization is defined as the deliverance of man first from religious and then from metaphysical control over his reason and his language.

He also differentiated the meaning of secularization and secularism where the former implies a continuing and open-ended process in which values and worldviews are continually revised in accordance with evolutionary change in history. The latter is like religion, projects a closed worldview and an absolute set of values in line with an ultimate historical purpose having a final significance for man. Secularism denotes an ideology and secularization is the process.

S. M. Naquib (1993) again stated that the weakening of the Muslim world had made possible the Western colonization of significant part of that world from the $17^{\text {th }}$ century onwards. With the colonization and cultural control, the West was able to inculcate the projection of its worldview in the Muslim mind and hence to dominate the Muslims intellectually. The dissemination of the Western worldview was gradually accomplished through the educational system based upon a concept of knowledge and its principle that would bring about the deIslamisation 
of the Muslim mind. In the context of education system, it becomes secular if:

i. The education philosophy is not based on the teachings of Islam.

ii. Where the subjects being taught were detached from the Islamic foundations

iii. The curriculum was not founded on Islam

iv. Absence of Islamic value system

\subsection{Dualism in Educational System}

Dualism refers to the existence of two educational systems that is the traditional, religious and the secular, national system. As a result of this dichotomy, the system of education became a means of dividing the Ummah (Muslim community) and draining its energy (Taha Jabir, 1989). Rosnani (2004) equally warned that this educational dualism bears negative consequences for Muslims. Both systems produce half-baked Muslims who do not possess the integrated Islamic personality. It is even worse when graduates of both systems who subscribe to opposing worldviews, cannot see eye to eye on social, economic and political problems.

\subsection{Holistic Personality}

The National Education Philosophy states that the thrust of education and training will be human resource development. It further states that it is not only aimed to equip individuals with the appropriate knowledge and skills but also to produce responsible citizens with strong moral and ethical values.

It is believed that the bearer of civilizational development is not just the youth or the country's younger generation alone, it also depends on parents who educate and left the strongest influence on them. In the same time, the community mould that shaped the environment has equally strong influence on personality. Normally, youngsters learn from their role-models and other significant individuals. In the absence of a true and right role-models, it is difficult to see that the aspiration of developing a holistic personality to come along with physical developments could be materialized.

\subsection{Islamisation of Education}

Education is defined as a process in which we discover and develop our potentials and abilities. According to Hasan Langgulung (2001), education can be seen from three aspects:

\section{Individual}

Human is seen to have a bunch of potentials and abilities that are unknown either to the individual themselves or to others in general. Therefore, through the education process, all these potentials and abilities will be discovered and developed to benefit the individuals as well as the societies.

\section{Society}

From the society's aspect, education is seen to play its role as an instrument to internalise and transmit the culture from one generation to another.

\section{Interaction between individual and society}

Education as a process of interaction between the individual and the society that is the development of potentials of the individuals will contribute to the betterment and improvement of the societies.

The task now is to rediscover the relevant process. Therefore, according to Hasan Langgulung (2002), the Muslims have to avoid two errors that is blind copying of the West and an outright rejection of everything Western because modernization is not Westernization. They should acquire Western science and technology selectively, creatively and critically. The Muslims must find answers to their own problems in the light of the eternal message of the Quran.

Accordingly, there are several reasons that contribute to the need for Islamisation of education:

1. The Prophet SAW said: "One day you are going to fall blindly to the system before you, even if they get into the lizard hole, you will fall too". This has been elaborated in details by Prof. Dr. Malik Badri (2001) in his book, "The Dilemma of Muslim Psychologists".

2. S. M. Naquib (1993) stated that the present Muslims dilemma is caused by:

a) the confusion and error in knowledge, creating the condition for :

b) the loss of adab within the community. These two conditions will lead to

c) the rise of leaders who are not qualified for valid leadership of the Muslim community, who do not possess the high moral, intellectual and spiritual standards required for Islamic leadership. 
All the above roots of our general dilemma are interdependent and operate in vicious circle.

3. Omar H. Khaleefa (1997) in his article, "An attempt toward an ummatic psychology", stated that the reality of the ummah is that, the present psychology in the ummatic culture is divorced from both the creative past of Islamic civilisation and the creative present of western thought. The spirit of imitation in psychology (modernization) has been exported from the West, not the techniques and methods (modernity). The Muslims have taken from the past the spirit of imitation (taba'yah), not the spirit of vitality and productivity.

\subsection{Integrated Approach in Education}

Taha Jabir (1989) identified three basic approaches in the present state of thought among the Muslims:

1. The traditionalist approach which considers the Ummah's traditional thought to be self-sufficient and capable of being presented as it is or with very little alteration. This approach holds that the Ummah's intellectual life can be formed and organised, that the structure of its civilisation can be built on this basis. This approach is described as the approach of authenticity.

2. The contemporary Western thought and its world-view where without it a modern culture and civilization cannot be built even if any consequent negative aspects are the price which must be paid if it is to be established. The view is often described as modernistic.

3. The eclectic approach in which one must select from traditional thought what is most sound, and from 'modern' contemporary thought that which one considers and proves to be correct, and weld the two.

According to Sidek Baba (2000), integration and illumination is a process which demands proper planning and undertaking. He added that to create an effective process of integration, three things need to be done:

1. The Development of an Epistemological Foundation i.e. a foundation for integration

Since the nature of the Western epistemology is characterized by a dualism, it is important that the methodology of an Islamic curriculum should be essentially different from that of the Western. Both curriculum and methodology should be fundamentally shaped by the Islamic ethos and values which should be extracted from past legacies that is to bring into picture the concept of lita'arafu (interaction).

\section{The Development of Institutions to Implement the Process}

Institutions are established with certain philosophy to attain certain objectives. Islamic institutions should aim at fulfilling the tawhidic (the principle of tawhid - Oneness of God - in this context could be read to mean 'Islamic') objectives in an integrated manner which is not bound by space or time. This approach will include excellent facilities such as good laboratories, information systems, institutions of higher learning, and well equipped libraries. An excellent research tradition should be part of this approach and it should also promote a healthy academic atmosphere.

\section{The Development of Scholarship}

The orientation of knowledge must give high regards to the value-based knowledge. The integrated approach should be applied so that the curriculum becomes holistic and gives due regard not only to spiritual matters but also temporal ones. The study of science should be integrated with religion and the tradition of scholarship itself demands well-disciplined people in research, producing authentic and original books, materials and software in this cyber era. Efforts should be made to absorb the Western knowledge into tawihidic paradigm without sacrificing the Islamic epistemological foundation and value system.

\section{Implication on Human Capital Development in Malaysia}

The development of Islamic education in Malaysia is tremendous and receiving an over whelming support from the community. From what initially started as informal and done in small gatherings, it is now recognised as an important educational institutions.

An integrated approach in the education content whereby Islam stands at the core of the system grows very rapidly. From the elementary most level, namely the kindergarten to the highest level in the university, an integrated approach to education are implemented. The contents of Islam in subjects taught are found well entrenched in the curriculum.

Not just in the government schools, prívate sectors who involved in education at primary and secondary schools are actively playing their roles by establishing their own Islamic schools. They are however registered with and regulated by the Malaysian Ministry of Education. In their curriculum, apart from the normally taught academic subjects such as mathematics, science and history, a greater detailed Islamic reigious subjects are equally given 
strong attention. These subjects include knowledge of the Quran, Sunnah, Islamic civilisation, Islamic jurisprudence, Islamic history, Islamic conduct (akhlaq) and philosophy. They are taught side by side with the other academic contents under the same roof.

In a more recent development, a specialised international university, namely the International Islamic University of Malaysia was established. The university employs a unique methodology in its education system, having Islam at the core of its foundation. In the same time, knowledge which is loosely called 'conventional' or 'western' to some is not neglected. The approach is synergistic and eclectic in nature.

More Muslim parents are convinced that an educational institution which covers both parameters of education in their content and environment are better options for their children to study. Interestingly, an institution such as the International Islamic University in Malaysia attracts non-Muslims to study and to work in the university. The curriculum is uniquely designed. In the law faculty of this university, Islamic laws are taught next to conventional laws. In the economics faculty, conventional and the Islamic economic systems are both taught to the students. In the education faculty, the Islamic educational philosophy, psychology and sociology are taught together with their conventional counterparts. All facuties in the university offered postgraduate programmes leading to master and $\mathrm{PhD}$ and all are offering integrated approach to their analyses and studies.

The National Bank of Malaysia (Bank Negara Malaysia) set up a specialised higher learning institution called INCIEF (International Center for Education and Islamic Finance). This institution offers profesional courses up to doctoral level to train a highly specialised professionals in the field of Islamic banking, finance and economics. The principles of Islamic transactions are now translated into a working and operational banking, financial and economics systems. The non-Muslim bank owners are equally practising Islamic banking system and it proved to be practical and profitable. This illustrates the successful result of such integrated approach in the education system.

\section{Conclusion}

As we have discussed earlier, the Malaysian education system has undergone a series of developments in order to enhance its quality. Such metamorphosis as a result of numerous reforms allowed better education to be given to the students in Malaysia. The reforms were not easy as we inherited external philosophy, thoughts, curriculum and system from our previous colonial masters. As time goes by, the education system in Malaysia managed to find and locate its local identity which is more indigenous in nature, namely founded on Malay and Islam. These two thrusts had been embedded in the Malaysian national education curriculum being universal values though at initial stage received some form of resentment.

In Malaysia, it is not easy to develop an education system which could satisfy everybody given the fact that the country is multi religious and multi cultural in nature. It has almost a balanced composition between the Malays and non-Malays as well as Muslims and non-Muslims. Under these circumstances, an integrated approach in education would be essential in its reform.

Malaysian made a shift from a conventional system to the Islamic System. Eclectic model provides an opportunity for the shift to take place smoothly. The teaching of Islam is practiced symbiotically in a modern system and setting in the most practical manner.

The examples provided are some of the practical implications of the practice of eclectic model in the Malaysian education system whereby the subjects of Islam are being combined with the Western context of the subjects.

A good system must be followed with a good continuation. That will ensure sustainability and growth. In this regard, scholars, particularly those who graduated from this system of eclectic model must generate more ideas and share their efforts to contribute effectively towards a sustainable and progressive development of the system. Feedbacks from industrial players must also be sought from time to time to ensure that the model is effective in meeting the industrial needs.

\section{References}

AbdulHamid, A. AbuSulayman. (1994). Islamisation: Reforming Contemporary Knowledge. London: International Institute of Islamic Thought.

Andersen, L. E. (2001). Low Social Mobility in Bolivia: Causes and Consequences for Development. Germany: Kiel Institute of World Economics.

Hasan, Langgulung. (2001). Islamisasi Pendidikan Dari Perspektif Metodologi: Journal Pendidikan Islam, 3(9), 17-32

Hasan, Langgulung. (2002). A Psycho-Pedagogical Approach to Islamisation of Knowledge. Kuala Lumpur: International Islamic University Malaysia. 
Idris, Zakaria. (2002). The Political Aspects of Avicenna's General Theory of Cosmology \& the HumanSou. Bangi: Penerbit UKM.

Malik, B. Badri. (2001). The Dilemma of the Muslim Psychologist. Translated. Fadlullah Wilmot, "Dilema Ahli Psikologi Islam". Kuala umpur: Medina Books.

Omar, H. Khaleefa. (1997). The Imperialism of Euro-American Psychology in a Nonwestern Culture: An Attempt toward an Ummatic Psychology: The American Journal of Islamic Social Sciences, 1 (14). Report of World Conference on Islamic Education.

Rosnani, Hashim. (2004). Educational Dualism in Malaysia: Implications for Theory and Practice. Kuala Lumpur: The Other Press.

S. M. Naquib Al-Attas. (1993). Islam and Secularism. Kuala Lumpur: ISTAC.

S. M. Naquib Al-Attas. (1999). The Concept of Education in Islam: A Framework for an Islamic Philosophy of Education. Kuala Lumpur: ISTAC.

Sidek, Baba. (2000). Integrated Knowledge in the Tawhidic Curriculum: Muslim Education Quarterly. Cambridge: The Islamic Academy. 2 (17).

Sufean, Hussin. (1996). Pendidikan di Malaysia: Sejarah, Sistem dan Falsafah. Kuala Lumpur: Dewan Bahasa dan Pustaka.

Taha Jabir al-Alwani. (1989). Outlines of A Cultural Strategy. London: International Taha Jabir al-Alwani (1989). Outlines of a Cultural Strategy. London: International Institute of Islamic Thought. 